\title{
En torno a la narrativa catalana contemporánea'
}

\author{
JUAN MIGUEL RIBERA LLOPIS
}

UNIVERSIDAD COMPLUTENSE

I. Tratando fundamentalmente los años de preguerra, pero refiriéndose también a novelistas de proyección sobre las décadas posteriores, publicaba en 1966 y en Serra d'Or J. Molas (1975: pp. 105-110) unas Notes sobre la novel.la catalana contemporània que advertían sobre no pocos rasgos históricos de aquella narrativa, advertencias que parecían ir de la aseveración a la crítica. J. Molas se refería al autodidactismo más instintivo que intelectual del narrador catalán, a la irregularidad de su casi siempre escasa producción, a una falta de imaginación que lo encerraba en el auto-biografismo más o menos modificado como fuente argumental esencial y al condicionamiento y obsesión por los problemas de lengua y estilo. A que su producción era fruto de un acto voluntarista que, creemos entender, sólo con dificultades se asentaba sobre una tradición difícil de rastrear y también de consolidar.

Por esas fechas, en 1961, en el Pròleg a la primera edición de Bearn, Llorenç Villalonga (1897-1980) escribía asimismo:

"Tots junts, els catalans del Principat, els valencians i els balears encara podem fer una novel.lística ambiciosa, amb una base suficient de lectors; si es reclouen recelosos o escèptics, cadascú en el seu àmbit, no faràn mès que tres novel.lístiques comarcals."

Ese criterio tocado de temor ante la mediocridad y el provincianismo siempre posibles, y particularmente aquel listado de puntos flacos de la narrativa catalana -sobre todo constatables en el tercio central de este siglo, marcadamente conflictivo para nuestra cultura- han sobrevolado sobre la historia posterior. En no pocas ocasiones se han traído a colación cuando, ni por mejor ni por peor, la situación ya era otra o ya iba siendo otra. Se han repetido aquí y allá con excesiva facilidad, por encima de su intención y su contexto, para cubrir un marco referencial. Creo que J. L.l. Marfany (1975:

\footnotetext{
' Conferencia pronunciada en la UNED, el 6 de noviembre de 1991.
} 
pág. 91) es de los pocos que ya en el momento de reeditarse el texto de J. Molas advirtió de su caducidad. Esa caducidad, en lo que se refiere aún hoy a la constatación de una falta de tradición, se vislumbra si atendemos a los modelos reconocidos gradualmente por narradores posteriores a aquella cronología. Hemos escuchado a Montserrat Roig (1946-1991) y a Carme Riera (1948), por ejemplo, reconocerse en la lectura de Llorenç Villalonga, Mercè Rodoreda (1908-1981), Caterina Albert-"Víctor Català" (1869-1966). Sabemos además que Mercè Rodoreda había leído tempranamente a Joaquím Ruyra (1858-1939) y que atendió, entre otros, los consejos de Francesc Trabal (1898-1957) o acudió a los modelos de éste y de C. A. Jordana (18931958). "Víctor Català" mantuvo intercambio de ideas con Joan Maragall (1860-1911) y con Narcís Oller (1846-1930). Esto por elegir unos nombres que nos van retrotrayendo paso a paso hasta los últimos decenios del ochocientos, constatando, creo, la existencia de un contínuum que - ciertamente con dificultades - se va perfilando en nuestro siglo; esto, a su vez, sin querer caer en el equívoco de presentar una creciente tradición que sólo se haya nutrido de genes propios. No sería esto más que una especie de compartido provincianismo si recordamos la advertencia de Llorenç Villalonga. La coordenada de lo propio está ampliamente compensada en esa creciente tradición con la lectura del vector extranjero. De nuevo, a modo de resumido ejemplo, véase como Quim Monzó (1952) parte de autores como Robert Coover, Donald Barthelme, Julio Cortázar, mientras como traductor elige a Ray Bradbury o D. J. Salinger; entiéndase cómo la novelística de Llorenç Villalonga tiene por telón de fondo a Marcel Proust, Anatole France, André Gide entre otros o cómo Mercè Rodoreda admira abiertamente a Katherine Mansfield o a Virginia Woolf; piénsese también en el trasfondo de las antinovelescas Oceànides de Eugeni D'Ors (1881-1954) que van de Charles Baudelaire a Gabrielle D'Annunzio sin por ello anular los referentes autóctonos; y recuérdese la función catártica que sobre la prosa de Narcís Oller pudo tener la opinión de Émile Zola.

La tradición narrativa de la que aquí tenemos que hablar, vista de este modo, sí existe. Con toda certeza rodeada de problemas, casi siempre de orden externo. $Y$ ha sido, en este sentido, el problema lingüístico referido por J. Molas el más constante a causa de la casi total ausencia, a lo largo de nuestro siglo, del catalán en las estructuras educativas. Asunto este que repercute tanto en la confianza del narrador en su primordial útil de trabajo como en la existencia de un público consumidor mínimamente normalizado. Pero aceptada con todo la existencia de esa tradición, sólo cabe preguntarse: ¿cómo es la narrativa catalana contemporánea?

II. Atendiendo al método positivista, trazado sobre el esquema evolutivo de las ideas estéticas de los siglos XIX y XX, la narrativa catalana permite, título a título, avanzar sobre ese camino. Sólo, tal vez, con un capítulo escurridizo. El inicial, el de la novela romántica, lo cual se razona por encontrarnos en una cronología en la que aún se está haciendo coincidir todo tipo de esfuerzos a favor de la regeneración catalana y durante la cual se confía en la labor 
preeminente de la poesía, perspectiva pronto corregida. La segunda mitad del siglo XIX, superponiendo no pocos componentes estéticos, conduce a una narratología finisecular en la que destaca Narcís Oller, autor que ha de despojarse de no pocos excesos post-románticos para acceder al positivismo y llegar a alabar el psicologismo de los narradores del cruce de siglos. Teniendo por base la experiencia simbolista, narradores como Raimon Casellas (18551910), "Víctor Català" o Joaquim Ruyra construyen un sólido corpus narrativo, cuyos planteamientos perviven, como han planteado J. Ll. Marfany (1975: pág. 63) y A. Yates (1975: págs. 152-153), entre los vericuetos de la geografía controlada por el noucentisme, voluntariamente anti-novelesca. Donde los planteamientos noucentistes y neo-noucentistes ya en los años veinte y treinta se ven colapsados por un formalismo que no cuaja - el caso de Carles Soldevila (1892-1967), por ejemplo- - y sólo descuellan cuando apuran los límites de la ortodoxia - véase Judita (1930), de Francesc Trabal-, la continuación de la novela en la preguerra se da sobre la base evolucionada de los logros modernistes. Así entiendo la producción de un Miquel Llor (18941966) y de un Sebastià Juan Arbó (1902-1984). Así incluso la más híbrida de jóvenes narradores de preguerra como Salvador Espriu (1913-1985) o los ya citados Villalonga y Rodoreda.

La guerra civil y la inmediata postguerra cortan ese proceso. La cultura catalana se ve condenada a repetir la historia y las letras catalanas, la narrativa en concreto, a cruzar un desierto - sembrado de creación a puerta cerrada, de arriesgadas salidas a la luz, de crecientes aventuras editoriales-que sólo parece comenzar a superarse de finales de los años cincuenta a los años sesenta. En ese paréntesis la evolución creciente de la narrativa y su correspondencia con las coordenadas occidentales quedan varadas. La propia formulación del lenguaje narrativo queda cercenada, aspecto que quizá sólo ayuda a paliar la traducción al catalán de los títulos fundamentales, continuando la tradición del primer tercio de siglo. Sobre esa base - permítaseme resumir ahora más que nunca- - se relanzará la narrativa en catalán atendiendo tanto al creciente estado de normalización cultural que, aun paraoficialmente, va permitiendo el franquismo como a la presencia de los narradores sobrevivientes de la preguerra y a la aparición de nuevas promociones. En una situación que sí remite a grandes trazos al listado de J. Molas. Defectos o limitaciones que había que superar, y esa era la cuestión tal vez esencial si se quería ganar la atención de un público lector. Localizados en esa dinámica, la nueva y creciente nómina de narradores, superadora del posible desfase cronológico, instalará la producción catalana en un amplio abanico que, por dar dos puntos de referencia, va de la añoranza provocadora de Terenci Moix (1945) a los planteamientos de fractura de Biel Mesquida (1947). Y hasta todo un capítulo más reciente sobre el que volveré antes de acabar estas páginas.

Para razonar desde adentro esa historia disponemos además de todo un material muy esclarecedor, informativo en torno a la gestación de textos, propuestas de estilo, confesión de dudas firmadas por los propios narradores. 
Narcís Oller, en sus Memòries literàries. Història dels meus llibres (1913-1922) y también en su correspondencia con los maestros de la novela castellana decimonónica como Galdós, Pardo Bazán, Pereda, Valera explicita la entrada del catalán en el realismo. En carta de 1884 de Oller a Galdós -y déjenme contarles que lo único que el segundo no perdonaba al primero era que escribiera en catalán y que, como le decía en otra misiva de 1886, "....ólo usted me hace simpática temporalmente una lengua, que no existiría para mí, sino se contara V. en el número de los cultivadores de ella y en el más raro aún de los buenos novelistas españoles"--, el catalán, les decía, escribía a don Benito:

"Escribo la novela en catalán porque vivo en Cataluña, copio costumbres y paisajes catalanes y catalanes son los tipos que retrato, en catalán los oigo producirse cada día, á todas horas, como usted sabe que hablamos aquí. No puede usted imaginar efecto más falso y ridículo del que me causaría á mí hacerlos dialogar en otra lengua, ni puedo ponderarle tampoco la dificultad con que tropezaría para hallar en paleta castellana cuando pinto, los colores que me son familiares de la catalana (...). ¿No cree usted que el lenguaje es una concreción del espíritu? ¿Como divorciarlo pues de esa fusión que existe de realidad y observación en toda obra realista? Para mí las voces catalanas son como los olores que me traen asociación de ideas; una asociación de ideas que las imprime especial valor."

Raimon Casellas, en un artículo de 1893, formula la poética de la prosa modernista:

"Construcción monótona de ciertas oraciones, cuyos giros y vocablos, repetidos hasta el extremo, chocan por lo desabridos e inusitados; mas por lo mismo que chocan se pegan al oído y se imponen a la imaginación (...). Esas cantilenas de una misma frase, estas letanías de un mismo vocablo, este porfiado machaqueo de un mismo sonido, acaban por hipnotizar el alma del oyente, hasta llevarlo a ciegas y sin voluntad, por el camino angustioso de la sugestión."

En la glosa II de La Ben Plantada (1911) Eugeni D’Ors consagraba una poética opuesta que, ante sugestión y lirismo, preconizaba distanciamiento e ironía:

«Guarda`t, guarda`t, admiració meva, d'empènyer-me a lirisme, quan em cal tractar de la figura de la Ben Plantada. Ni a comparances et donis ni els mots imprecisos i prestigiosos, apel.ladors fàcils a la sug. gestió fàcil, et sàpiguen temptar. No cantis res, no exaltis res, no barregis res. Defineix, compta, amida. Poguessis dir com Sthendal, foll no obstant de passió per l'església de Sant Pere de Roma, en començar-ne la descripció: "Voici des détails exacts.» 
Se origina ahí un debate que conduce a textos tan esclarecedores sobre la novela de preguerra como son en 1925 los de Carles Riba (1898-1959) y Josep Maria de Sagarra (1894-1961) - Una generació sense novel.la, La por a la novel.la-, eje de la polémica entre criterios neonoucentistes y anti-noucentistes. Polémica y realidad que diseñan un espectro donde debaten la herencia modernista y los nuevos dictados teóricos. Joan Puig i Ferrater (1882-1956) confiesa en Vida interior d'un escriptor (1928) que,

“... havent triomfat darrera d'ell una generació més estudiosa i culta, ell s'havia sentit com indefens i arraconat amb el seu instint. Llavors començà de cercar fórmules i principis, d'estudiar amb una avidesa febrosenca, per tal de no trobar-se retardat davant la nova generació. I durant llarg temps havia fluctuat entre la seva primitiva fe i la creença en la superioritat de la generació jove, de la qual havia abraçat les teories sense tenir-ne la preparació. Això l'havia portat a escriure unes obres fredes i desmanyotades que havien estat a punt de fer-li perdre tot crèdit literari (...). Fou una època angoixosa durant la qual va debatre's amb multitud de teories que després d'haver-lo fet anar de tomballons el deixaren inerme per a tota creació viva i original".

Del período de postguerra permítaseme sólo mencionar la doble labor de Joan Sales (1912-1983). Como novelista, autor de Incerta glòria (1956-1968). Como director literario de "Club Editor". puerta de entrada para traducciones todavía pendientes en catalán y para la potenciación de la narrativa experimental. No transcribo ahora ningún fragmento de sus significativos prólogos por cuestiones de espacio. Sólo una breve cita sobre algo a lo que me he venido refiriendo, el público lector. En 1964, en el Pròleg a la segunda edición de La plaça del Diamant, de Mercè Rodoreda, escribe:

“... existeix un públic català que a la seva fidelitat exemplar a la llengua postergada uneix una capacitat no menys exemplar per a descobrir tot sol, enmig del silenci quasi absolut que les envolta, les obres realment valuoses. Com ja hem dit en altres ocasions, és gràcies a aquest públic que ha estat possible la supervivència d'una literatura catalana ambiciosa a través d'un quart de segle tan difícil i malgrat l'estrèpit eixordador de tanta publicitat intrusa".

Contando con ese público, y mediante la producción e información sobre la historia íntima de esa misma producción por parte de sus propios autores hábito que no ha hecho sino crecer-, se ha dibujado la existencia de una narrativa a la que podemos acceder por cualquiera de esos umbrales. Narrativa que. también es importante decirlo, cuenta desde el siglo XIX con una destacada sucesión de críticos y estudiosos — Joan Sardà, Josep Yxart, Rafael Tasis i Marca, Joan Triadú, Joaquim Molas, Jordi Castellanos. Alan Yates, Carme Arnau, etcétera-, compositores de un imprescindible aparato crítico a su alre- 
dedor. Pero, constatada esa realidad, concédanme benévolamente el derecho a una pirueta, a hacer un poco de abogado del diablo y preguntar: ¿,por qué una narrativa catalana?

III. A modo de epílogo no herméticamente referido a la materia aquí tratada, añadiré unas consideraciones. En un momento en que incluso la romanística medieval se plantea, atendiendo a cuestiones de orden supranacional, que no debieron existir literaturas románicas sino literatura medieval en lenguas romances junto a las de otra expresión lingüística, creo que desde la perspectiva de lo contemporáneo estamos obligados a acrecentar ese punto de mira. A poco de la publicación de la traducción castellana de American Psycho (1991), de Bret Easton Ellis, una comentarista de la última edición de un reciente festival de cine, tratando un título soviético, indicaba que nada diferenciaba una ficción de la otra a no ser la carencia de medios del personaje de la segunda. Pongo este ejemplo no sólo para destacar cómo, cada vez más, creadores de marcos aún distintos coinciden en temas y tratamientos; también para que pensemos en el mecanismo del receptor que rápidamente equipara productos. La supranacionalidad literaria es, más y más, un hecho constatable. Hubo un realismo fantástico que propició el lanzamiento de un boom hispanoamericano en el que no todo lo incluido cabía bajo aquella etiqueta y raudamente hubo realismo fantástico en todas las literaturas occidentales, incluida la catalana, con títulos nada desdeñables, uno debido a Maria Antònia Oliver (1946), algún otro de receta como los debidos a Baltasar Porcel (1937) y todo un corpus novelístico, el de Joan Perucho (1920), cimentado en una profunda estrategia barroca. Algunas de aquellas literaturas, sólo a rastras del fenómeno, cayeron en la cuenta de que ya lo habían practicado. Pero no es esto lo que aquí interesa sino la cuestión del creciente equiparamiento universal.

Si eso es así a grandes rasgos, si ha estado siendo así y de manera creciente a lo largo del siglo, ¿por qué el empeño de las letras catalanas, por añadidura en un entorno hostil, en marcar su propia historia? Carme Riera lo contestaba en una columna periodística: por siete millones de razones, cifra que remite a la actual población catalanoparlante. Y eso dicho y hecho por una autora que ciertamente teme la traducción pero que, sabiéndose sujeta al interés literario y al mercado editorial, ha cuidado siempre que ha podido los derroteros de la traducción de sus textos y en la actualidad confiesa trabajar al unísono el original catalán y la versión castellana que rápidamente deberá librar. Siete millones de razones, por tanto, en un espacio más amplio, común con otros muchos millones de razones y destinados a la contaminación cultural o a sujetar su experiencia a códigos cada vez más supranacionales.

El espectro socio-cultural catalán de los últimos años se ha comenzado a poblar de generaciones nacidas en el creciente estatus de normalidad cultural que debe ir propiciando la cooficialidad constitucional. Se va generalizando el acceso del catalán a la educación y a los medios de comunicación. Se va normalizando un mercado cultural en catalán. Va creciendo un público nuevo dis- 
puesto a consumirlo. Público que es parte de la cifra mencionada, que consume pero que ya, por edad, comienza a producir. Su producción ha detectado que si bien aprovecha y respeta parte del producto de la historia inmediatamente anterior, también está dispuesto a imponer sus propias formulaciones. Estas pasan por una expresión lingüística que es la del catalán estándar y urbano en que se les ha comenzado a educar y, en ocasiones, por unos contenidos que cada vez pueden alejarse más de las constantes catalanas para instalarse en la supranacionalidad que propician los medios actuales. Esa presencia - en la narrativa protagonizada por nombres como Sergi Pàmies (1960), Maria Jaen (1962) o Gabriel Galmés (1962) — ha provocado por parte de algunos sectores una polémica de la que los últimos salían descalificados con la denominación de autores light. ¿Por responder a su tiempo y a sus experiencias? ¿Por no repetir las de algunos de sus antecesores que pueden estar cayendo en la dictadura de su caduco liberalismo fuertemente comprometido con la regeneración catalana de la manera en que la época lo exigía? Dejaremos abiertos los interrogantes hasta que la necesaria distancia nos permita ser más objetivos y la producción narrativa de todos ellos, contrastada, propicie el más estricto juicio crítico. En este preciso momento lo que sí hay que reconocer es que esas nuevas promociones prueban la adecuación de las letras catalanas con las corrientes occidentales, aspecto que muchos críticos e historiadores en ocasiones han echado de menos ante la producción en catalán. Supranacionalidad literaria que hoy por hoy no entra en conflicto con el uso de la lengua propia, ni en el caso catalán ni en los más próximos. Si en aras de esa supranacionalidad un día se impone la sustitución lingüística, que sea por proceso evolutivo cutural y no por imposición o por no tener conciencia de la propia tradición.

Instalada en esa encrucijada, la narrativa catalana vive entre aristas de diversa índole. Por ejemplo, en un momento editorial nada desdeñable-mejores tiempos para la prosa que para la lírica-, la producción en catalán no deja de moverse en un espacio comercial minoritario en el que, además, de sus siete millones de razones un importante porcentaje aún es diglósico. En otro sentido, la superposición de generaciones de escritores ofrece un discurso plural, pluralidad de voces siempre enriquecedora para la literatura.

\section{BIBLIOGRAFIA}

Marfany, J. Ll. (1975): Aspectes del modernisme, Barcelona, Ed. 62.

Mol.As, J. (1975): Lectures crítiques, Barcelona, Ed. 62 (páginas 105-110).

YATES, A. (1975): Una generació sense novel.la? Barcelona, Ed. 62. 